\title{
SESSÃO DE ENCERRAMENTO
}

Na Sessão de Encerramento realizada no Hotel Tambaú, Sede do XXV Congresso Brasileiro de Enfermagem a Presidente da ABEn, Dr. ${ }^{a}$ Glete de Alcântara, diante das autoridades presentes e representadas e das congressistas, outorgou à Dona Clarice Ferrarini, Secretária Executiva da ABEn, o Título de Sócio Benemérito, aprovado na Assembléia de Delegados do XXIV Congresso Brasileiro de Enfermagem realizado em Belo Horizonte em 1972.

\section{ATOS DO PODER LEGISLATIVO}

\section{LEI N.O 5.S.05 - DE 12 DE JULHO DE 1973}

Dispōe sobre a criação dos Conselhos Federal e Regionais de Enfermagem e dá outras providências.

O Presidente da República

Faço saber que o Congresso Nacional decreta e eu sanciono a seguinte Lei:

Art. 1. São criados o Conselho Federal de Enfermagem (COFEN) e os Conselhos Regionais de Enfermagem (COREN), constituindo em seu conjunto uma autarquia, vinculada ao Ministério do Trabalho e Previdência Social.

Art. 2. 0 Conselho Federal e os Conselhos Regionais são órgãos disciplinadores do exercício da profissão de enfermeiro e das demais profissões compreendidas nos serviços de enfermagem.

Art. 3. $O$ Conselho Federal, ao qual ficam subordinados os Conselhos Regionais, terá jurisdição em todo o território nacional e sede na Capital da República.

Art. 4..$^{\circ}$ Haverá um Conselho Regional em cada Estado e Território, com sede na respectiva capital, e no Distrito Federal.

Parágrafo único. O Conselho Federal poderá, quando o número de profissionais habilitados na unidade da federação for inferior a cinquenta, determinar a formação de regiões, compreendendo mais de uma unidade.

Art. 5.' O Conselho Federal terá nove membros efetivos e igual número de suplentes, de nacionalidade brasileira, e portadores de diploma de curso de enfermagem de nível superior.

Art. 6. ${ }^{\circ}$ Os membros do Conselho Federal e respectivos suplentes serão eleitos por maioria de votos, em escrutínio secreto, na Assembléia dos Delegados Regionais. 